UNTAG Law Review (ULREV)

Volume 3, Issue 1, May 2019, PP 39-56

ISSN 2549-4910 (online) \& ISSN 2579-5279 (print)

http://jurnal.untagsmg.ac.id/indeks.php/ulrev/indeks

www.fakhukum.untagsmg.ac.id

\title{
PREVENTION AND ERADICATION OF DRUG TRAFFICKING IN INDONESIA
}

\section{Endeh Suhartini}

Lecture of Faculty of Law, University of Djuanda Bogor

Email : endeh.suhartini@unida.ac.id

\section{Martin Roestamy}

Lecture of Faculty of Law, University of Djuanda Bogor

Email : martin.roestamy@unida.ac.id

\section{Ani Yumarni}

Lecture of Faculty of Law, University of Djuanda Bogor

Email : ani.yumarni@unida.ac.id

\begin{abstract}
Many countries including Indonesia have concerned about the increase of drug trafficking. Currently Indonesia has been in the situation where there is an "Emergency on Drugs Trafficking”. Lot of efforts to solve and prevent the growth of drug trafficking has been done to save young generation. Criminal Acts on Drugs which have been spread out need to be cut off because the drug trafficking has happened nationally and even has crossed international boundaries.

The Aims of this research are to identify and analyses necessary actions to prevent and solve the drug trafficking. Then, to find an ultimate solution in handling arising obstacles within such prevention and eradication of drug trafficking in Indonesia.

This research uses a juridical normative approach method which reviews theories, concepts, legal principals, and prevailing rules and regulations. Moreover, it also applies an empirical approach as supporting study to gain more factual data.In conclusion, illegal drug trafficking has become both national and international social issue and even a legal issue in society. Certain legal actions are required to take to prevent and solve the drug trafficking in Indonesia, which one of them is by rules and regulations. Law Number 35 of 2009 regarding Drugs is a legal basis for the prevention and eradication of drug trafficking in Indonesia.The research limitation is focus on increasing and preventing drugs should be supported by all parties of the family, community and government.Drugs is an international and national case that is difficult to overcome considering their networks are hidden and require special skills where
\end{abstract}


necessary national and international cooperation so that drug circulation can be overcome quickly

Keywords : Drugs, Prevention, Eradication, Law, Drug Abuse

\section{INTRODUCTION}

As mentioned in Article 1 Section 3 of the 1945 Constitution of the Republic of Indonesia: "Indonesia is a country that based on the rule of law". This article clearly states that Indonesia is a state law ("rechstaat") and not a state of power ("machstaat") in which the whole actions and deeds of its people and government must comply the law. Then also it is because Indonesia is not a state of power which belong to a certain person because of his unlimited power. However, a mandated power must be held according to according to according to the law and should not use inappropriately. ${ }^{1}$

Indonesian Constitution states that all people of Indonesia are entitled to equal treatment before the law as stated in Article 28 D, Paragraph 1 of the 1945 Constitution. ${ }^{2}$

Criminal Act trend of drug abuse in Indonesia has developed rapidly which required to get attention from public.

In the beginning, the increase of drug criminal act is done with traditional way which come from the seller to buyer directly like transaction of goods. However, along with development of technology, the criminal act has become the long network system with its communication system. This fact causes that the seller and the buyer does not have to meet each other. This also happens to the criminal act involving in drug production where the finder that involve in the production process (material concocted, raw material supplier, packaging, and distributor/courier) which has already had a system that is difficult to be anticipated by the officer. With this new method, this creates difficulty for the officers to disclose and eradicate the illegal drug trafficking in Indonesia. ${ }^{3}$

In Indonesia, drugs / "narkobastands for narcotics, psychotropics,other addictive materials. This terminology of "Narkoba" is familiar to be used by law enforcement apparatus such as policies (including National Anti-Drugs Agency), prosecutors, judges and prison officers.

Excepts drugs, other terms that used especially by Department of Health of Republic of Indonesia which is Napza, referring those three addictive substances: Narcotics, Psychotropic,

1 EndehSuhartini, Legal Perfective of Medical Care System For Prisoner and Detainees, International Journal OfCivil Engineering and Technology, 8 (9), 2017, Page 406-412.

2 Erma Rusdiana, Mediation Existence Criminal Penal Settlement, Journal UNTAG Law Review (ULREV), Volume 2, Issue 1, May 2018, PP 31-43, http://jurnal.untagsmg.ac.id/indeks.php/ulrev/indeks

3 Russell Butarbutar, "Kompilasi Hukum Pidana dan Aplikasinya di Masyarakat", Pondok Gede Bekasi, Gramata Publishing, 2016, Page. 139 
and addictive substance. ${ }^{4}$

Emergency alert of Drugs in Indonesia has become so relevant when the condition of drugs trafficking increase rapidly. In global, based on the Word Drug Report of 2017, issued by United Nations Office on Drugs and Crimes (UNODC), it is predicted that every one person from 1 billion people, or around 5\% from adult populations with age 15-64 years old, use drugs at least one time in 2015 (range: 158 million until 351 million), which means that the level of drug use among world population is stable for the past five years.

Globally, more than $11 \%$ of the drug users or around 29.5\% million people (approximately: 15.3 million until 43.1 million), are anticipated have been suffered from drug use. We can see that the drug use has become dangerous its users have become addictive and needs treatment. ${ }^{5}$

Opioids are substances that cause highest negative health impacts, but marijuana is still the most consumed in the world, with the annual prevalence around $3.8 \%$ of the adult's population or 183 million people (around 123 million until 238 million) have used marijuana last year. ${ }^{6}$

Following is the data regarding the global trends of drug users between 2006- 2015 that shows the global level (world) of the drug users that keep increasing.

Global trends in estimated number ofdrug users and people with drug user disorders, 2006 -2015

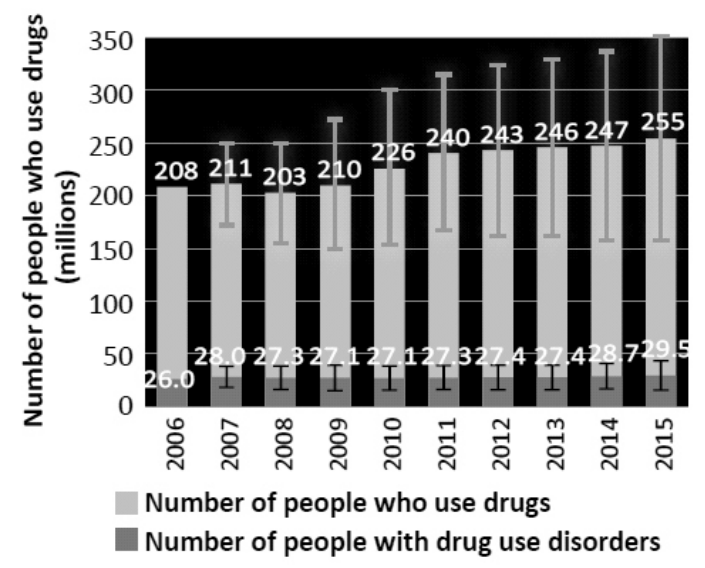

Source: UNODC, responses to annual report questionnaire. Note: Estimates are for adults (aged 15-64) who used drugs in the past year.
Global trends in the estimated prevalence of drug use and prevalence of people with drug use problems, $2006-2015$

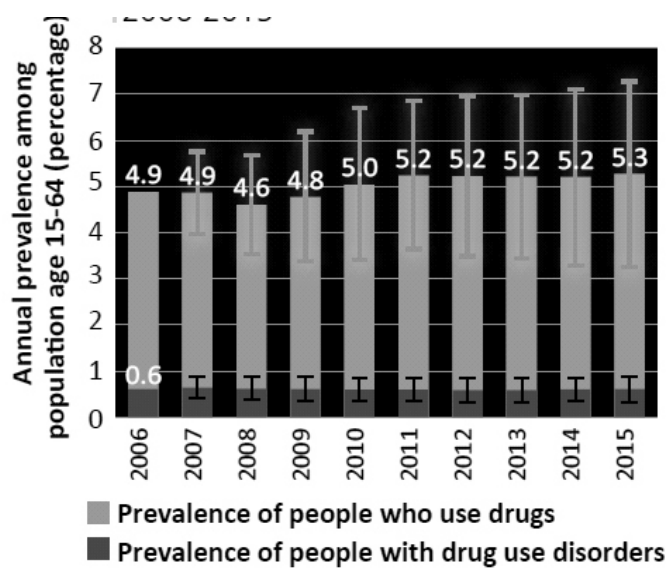

Source: UNODC, responses to the annual report questionnaire. Note: Estimated percentage of adults (aged 15-64) who used drugs in the past year.

4 Syamsul Hidayat, "Peran Badan Narkotika Provinsi Nusa Tenggara Barat dan Polisi Resort Kota Mataram Dalam Menanggulangi Pengedaran dan Penyalahgunaan Narkoba (Studi di Kota Mataram), Jurnal Hukum Jatiswara Fakultas Hukum Mataram” Volume 31 1-2 Maret 2016 ISSN. 0853-392X, Page. 137

5 United Nations Office on Drugs and Crimes (UNODC), World Drug Report 2017 - GLOBAL OVERVIEW OF DRUG DEMAND AND SUPPLY $\square$ : Latest Trends, Cross-Cutting Issues, Booklet 2 (Vienna-Austria: Division for Policy Analysis and Public Affairs-UNODC, May 2017), Page. 13

6 Ibid. 
prevalence of the mis-use in the rent rooms within 3 times survey. However, the numbers were still quite high, because the numbers of prevalence of drugs abuse especially in the special household is much higher compared to the general households. This indicates that the mis-use and drug trafficking possess certain elements in community. ${ }^{7}$

Prevelance Numbers of Drug Abuse in Lifetime and One Year

\begin{tabular}{|c|c|c|c|c|c|c|c|c|c|c|c|c|}
\hline \multirow{3}{*}{ Remarks } & \multicolumn{6}{|c|}{ Lifetime } & \multicolumn{6}{|c|}{ One Year } \\
\hline & \multicolumn{2}{|c|}{2005} & \multicolumn{2}{|c|}{2010} & \multicolumn{2}{|c|}{2015} & \multicolumn{2}{|c|}{2005} & \multicolumn{2}{|c|}{2010} & \multicolumn{2}{|c|}{2015} \\
\hline & $R T$ & $R K$ & $R T$ & $R K$ & $R T$ & $R K$ & $R T$ & $R K$ & $R T$ & $R K$ & $R T$ & $R K$ \\
\hline In the aggregate & 2.4 & 13.2 & 2.4 & 7.5 & 1.7 & 5.9 & 0.8 & 5.2 & 0.6 & 4.0 & 0.6 & 3.8 \\
\hline \multicolumn{13}{|l|}{ Age bracket } \\
\hline $10-19$ years old & 1.2 & 8.9 & 0.7 & 0.0 & 0.9 & 1.7 & 0.8 & 3.3 & 0.4 & 0.0 & 0.3 & 1.0 \\
\hline 20-29 years old & 5.1 & 14.3 & 4.2 & 2.8 & 1.8 & 6.5 & 1.8 & 5.9 & 1.5 & 1.9 & 0.9 & 4.6 \\
\hline More than 30 years old & 1.7 & 9.9 & 2.3 & 8.3 & 1.9 & $7.8^{\prime}$ & 0.3 & 2.5 & - & 4.2 & 0.6 & 3.6 \\
\hline \multicolumn{13}{|l|}{ Administrative location } \\
\hline City & 2.8 & - & 2.7 & - & 1.9 & - & 0.9 & - & 0.7 & - & 0.6 & - \\
\hline Regency & 1.3 & - & 1.5 & - & 1.4 & - & 0.5 & - & 0.4 & - & 0.6 & - \\
\hline \multicolumn{13}{|l|}{ Area Location } \\
\hline Campus & - & 13.4 & - & 0.0 & - & 6.4 & - & 5.7 & - & 0.0 & - & 5.0 \\
\hline Industry/Factory & - & 3.8 & - & 5.2 & - & 3.2 & - & 1.8 & - & 2.5 & - & 1.9 \\
\hline Office & - & 14.6 & - & 4.3 & - & 4.1 & - & 5.5 & - & 0.7 & - & 2.1 \\
\hline Market & - & 11.0 & - & 15.4 & - & 4.6 & - & 0.5 & - & 9.4 & - & 2.5 \\
\hline Entertainment place & - & 24.0 & - & 11.6 & - & 14.5 & - & 9.6 & - & 7.3 & - & 8.4 \\
\hline
\end{tabular}

From the disclosing side of the drug case which can be successful to be disclosed, shows the number that increase. This means the distribution and drug abuse gets more serious. Based on the data from Narcotics Information System (SIN), the total of drug cases that have been conveyed for the past five years (2012 - 2016) per year is $76.53 \%$. The highest increment from 2013 to 2014 is $161.22 \%$. In 2016, total cases that have been revealed were 868 cases, increasing $36.05 \%$ from 2015 . $^{8}$

7 Mufti Djusnir, et.al, Survei Prevalensi Penyalahgunaan Narkoba Pada Kelompok Rumah Tangga Di 20 Provinsi Tahun 2015 (Jakarta: Pusat Penelitian Data dan Informasi Badan Narkotika Nasional Republik Indonesia, 2016), Page. 73.

8 Pusat Data dan Informasi Kementerian Kesehatan RI, 'Anti Narkoba Sedunia 26 Juni'17' (Pusat Data dan Informasi Kementerian Kesehatan RI, 2017), Page 3. 


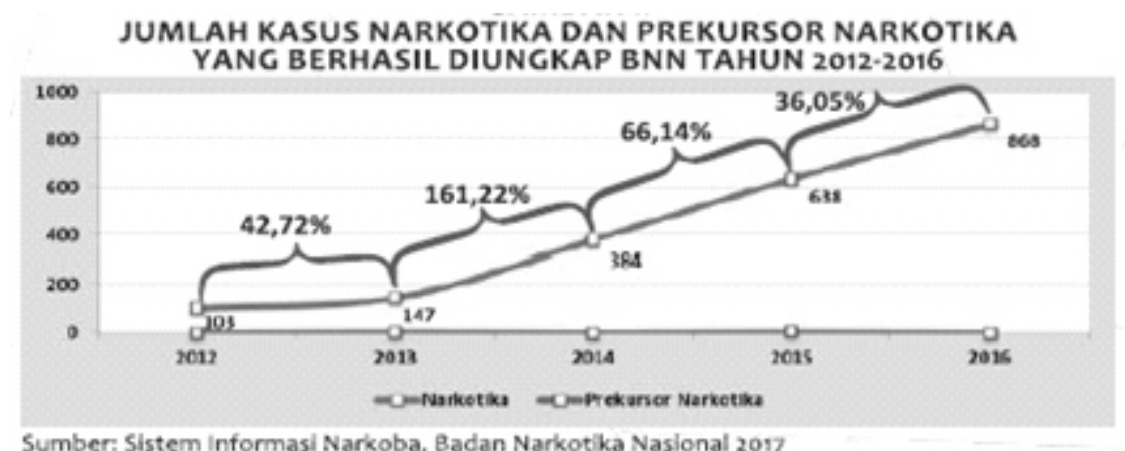

Seeing data that related to the distribution and mis-use of drugs, either in the scope of global or regional, it requires serious handling of drugs from entire aspects. Law enforcement aspect has become the ultimate effort to prevent and overcome the drugs abuse and drugs black market. Law No. 35 of 2008 regarding Narcotics is expected can be a juridical instrument that can save Indonesia from the danger of drugs abuse and drug black market.

Criminal subject of drugs criminal act in English is called "subject criminal narcotic crime", while in the Dutch is called "onderwepencrimineelverdovendecriminaliteit" which concepted as the suspect who convicted since he/she do drugs criminal act."

\section{Scope of Issues}

Issues that has been concepted in this paper set forth as follows:

1. How to prevent and solve drugs abuse in Indonesia?

2. What are the obstacles in the prevention and eradication of drugs in Indonesia?

\section{Research Method}

The research is conducted with normative juridical method. Normative juridical approach is the approach that performed based on main legal material by reviewing theories, concepts, legal principles and rules and regulations that related to this research. This research is also known literature approach which studying books, rules and regulations and other documents that has relation with the study.

This research is also conducted by performing the empirical method as supplementary material within for the research which by using direct empirical approach to the field by direct observation and interview, for instance, it is in Correctional Institution and to convicts of drugs and people.

9 Hj.Rodliyah dam H.Salim HS. “HukumPidanaKhusus,UnsurdansanksiPidananya”, Depok, RAJAWALI PERS,2017. Page.103 
Data that is obtained from the research field is connected to the theories and rules and regulation. Data is being analyzed, reviewed with the descriptive review which means it is described and analyzed to discuss and to gain the answer that is organized in the form of conclusion as the answer for the issue of of this research.

\section{Discussion}

\section{Prevention and Eradication of Drug Abuse and Illegal DrugTrafficking in Indonesia}

\section{General Review Regarding Drugs}

In etymology, drugs come from English "narcotic" that absorb from Greek "narko" that means "causing numb", which in the beginning it referred to medical terms for psychoactive that causing sleeping effect. ${ }^{10}$ Based on medical term, drugs or narcotics is a drug that can allay especially pain that come from abdominal cavity and thoracic cavity, which also may cause long condition dumbfounded or stupor consciously and give addictive effect. ${ }^{11}$

Narcotics term always being compared to the term of drug/ hazardous material with using Narkoba(narcotics and hazardous material) term. Other terms as introduced by Ministry of Health of Republic of Indonesia is NAPZA that stands for Narcotic, Psychotropic, and Other Addictive Substance.

NAPZA is material/substance/drug which if it enters into human body, it will affect the body especially brain/central nervous system, therefore it causes physicalhealth disturbance, psyches and its social function due to habits, addiction and dependency towards NAPZA. ${ }^{12}$

Meanwhile, general drugs based on rules and regulations Article 1 Number 1 of Laws Number 35 of 2009 regarding Drugs (Law of Drugs).

Definition of narcotics must be distinguishing with psychotropic that has different character as well. In Law of Republic of Indonesia, No. 5 of 1997 regarding Psychotropic (Psychotropic Law), what it defined as Psychotropic is substance or drug either natural or synthetic which is not narcotic that proactively through selected influence on the central nervous system that cause specific change to mental and behavior.

Between those two laws - Law of Drugs and Law of Psychotropic - have close connection, in which based on Article 153 of Narcotic Laws, it may be known that the validity Law of Drugs

10 Wikipedia, 'Narcotic', Wikipedia The Free Encyclopedia, $2017<$ https://en.wikipedia.org/wiki/Narcotic> [diakses pada 25 Januari 2018].

11 Fransiska Novita Eleanora, 'Bahaya Penyalahgunaan Narkoba Serta Usaha Pencegahan Dan Penanggulangannya (Suatu Tinjauan Teoritis)', Jurnal Hukum, Vol. XXV.No. 1 (2011), Page 411

12 Departemen Kesehatan R.I, Buku Pedoman Praktis Bagi Petugas Kesehatan (Puskesmas) Mengenai Penyalahgunaan Narkotika Psikotropika Dan Zat Adiktif Lainnya (NAPZA) (Jakarta: Perpustakaan Departemen Kesehatan R.I, 2001). 
does not change the validity of Law of Psychotronic. However, Annex of Law of Psychotropic regarding Psychotropic Type I and Type II have been repealed because DrugsLevel I in the Law of Drugs ${ }^{13}$. Pursuant to Law of Drugs, there are 3 (three) types of Drugs:

a. Type I of Drugs

Narcotics that may only be used to develop science and not for therapy and also has potential to cause addiction. Type of drug that include in this type: cocaine, heroin, marijuana, and gorilla tobacco

b. Type II of Drugs

Narcotics that may be used for medicine and can be used for therapy and/or for science and has high potential to cause addiction. Type of drug that include in this type: Alfasetilmetadol

c. Type III of Drugs

This type of narcotics is beneficial for medicine and is much used in therapy and/or for science and has low potential of addiction. Type of drug that include in this type: Asetildihidrokodeina

For the first time, Law of Drugs is enacted, some type of drugs is determined by Law of Drugs which then change of drugs classification is governed by Minister Regulation. Change of this classification is surely to accommodate the increase of abuse towards the new substance that has high potential to cause addiction that has not included in the Drugs type as governed in the Drugs Law.

The change of classification when this paper is organized is determined in Regulation of Ministry of Health of Republic of Indonesia Number 2 of 2017 regarding Change of Drugs Classification. ${ }^{14}$

\section{Implication of Drugs Abuse}

Drug with its addictive nature, if such additive substance is used correctly under medical supervision, therefore the affect is deemed as therapy. However, if such substance is consumed

13 This matter is detemined in Article 153 Law 35/2009 which mentions:

With the validity this Law:

a. Law No. 22 of 1997 regarding Drugs (State Gazette of Republic of Indonesia of 1997 No. 67, Supplement to Offcial Gazette of the Republic of Indonesia No. 3698); and

b. Annex of types of Phsycotropic of Type I and Type II as mentioned in the Annex of Law No. 5 of 1997 regarding Psycotroipic (State Gazette of Repulic of Indonesia of 1997 No. 10, Supplement to Official Gazette of Republic of Indonesia No. 3671) which has been remonved to the Drugs Type I based on this Law, has been revoked and stated no longer valid

14 Pemenkes No. 2 of 2017, Drugs Type I are 114 types, Drugs Type II are 91 types, and Drugs Type III are 15 types 
by somebody with non-medical and re-search purpose, such thing is called as drug/substance abuse which means a persistent or sporadic use and inconsistent with or without any relation with acceptable medical use. This brings to a definition of addictive substance that developed by WHP that become psychoactive substance that used and cause health disturbance both mentally and physically (harmful use). ${ }^{15}$

Besides its implication to health, drugs also cause other negative effect either towards the users/ personal abuse, or other implication that is harmful towards social-economy life, and implication toward the security threat and public order.

In the survey that conducted by BNN, Drugs Abuse and its Illegal Trafficking in the student groups identifies that the most talked of Impact of the Drug Abuse is impacts towards health and prison charge.

Proportion of this number is not quite far between finding in 2011 and 2016. The interesting part is the drug abuse users have opinion that they have more issues either with their own selves, other people, at schools even with law enforcement officer. However, they are powerless and cannot get away from their issues. Moreover, a drug problem is a stigmatic issue and disgrace for the families, therefore the narcotics or drug users become more isolated. ${ }^{16}$
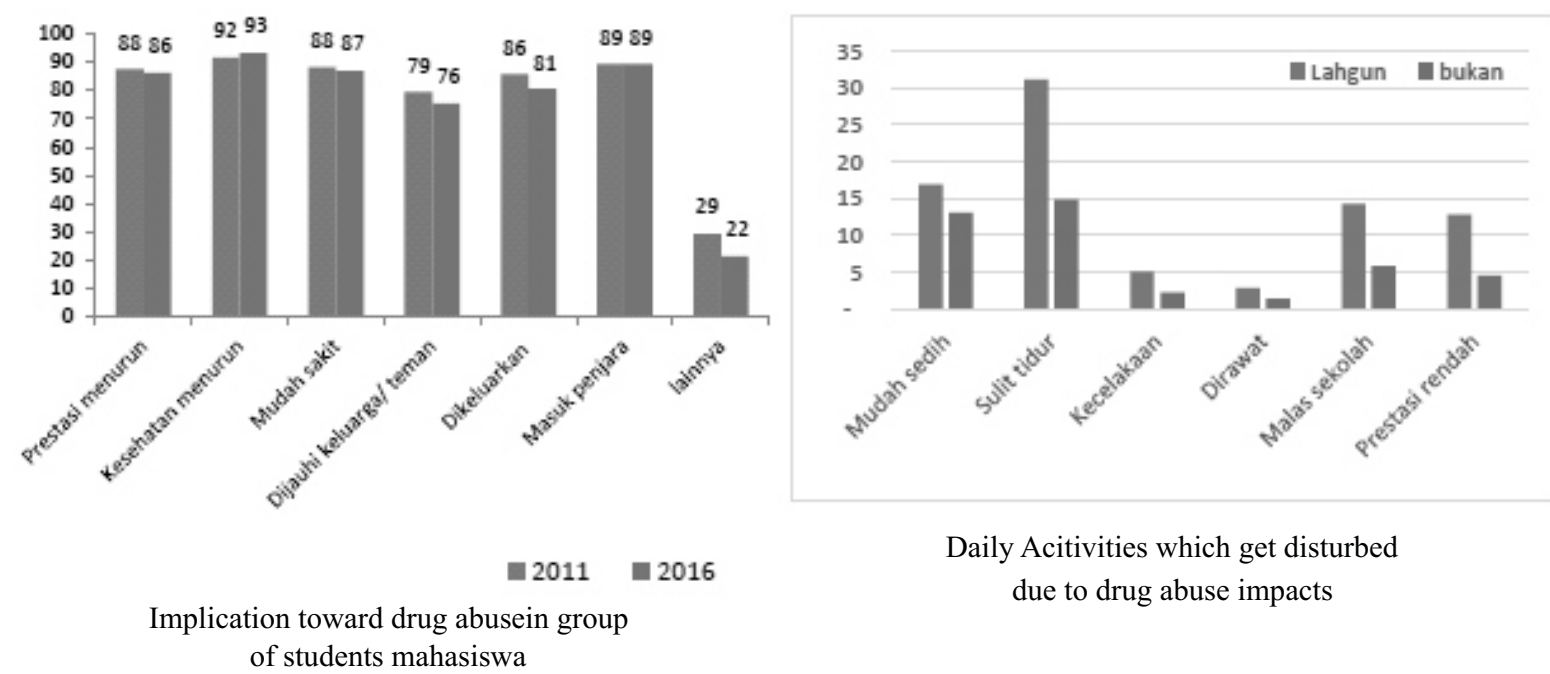

Daily Acitivities which get disturbed due to drug abuse impacts

Besides that, other negative effect is that the social aggresiveness that negatively influencing such as being in the fight, stealing, destructing stuffs, getting involve with the police, having issues with teachers at schools and selling drugs. From all those activities, the proportion that

15 Sabarinah Prasetyo dan Diah Setia Utami, 'Preverensi Sekunder Pemakaian Zat Adiktif', Buletin Jendela Data Dan Informasi Kesehatan, 2014, Page 23.s

16 Faisal Abdul Naser et., al., Hasil Survei Penyelahgunaan Dan Peredaran Gelap Narkoba Pada Kelompok Pelajar Dan Mahasiswa Di 18 Provinsi Tahun 2016 (Jakarta: Badan Narkotika Nasional Bekerjasama Dengan Pusat Penelitian Kesehatan Universitas Indonesia, February 2017), Page 39 
has higher social aggressiveness among drugs abuse compared to non-drugs abuse. ${ }^{17}$

Negative impacts of drugs to someone can be identified from two things: ${ }^{18}$

a. Physical transformation. Such physical transformation may occur depends on type of substance that be used but in general it can be categorized as follows: ${ }^{19}$

1) Addiction (ends when using NAPZA: walk unstably, talk slurred, be apathic, easy to fall asleep, be aggressive, and be suspicious

2). Overdose: short of breath, low heart rate, cold skin, slow breath/stop, die

3). Drunk on drugs: runny eyes and nose, non-stop yawn, diarrhea, pain all over body, rarely take a bath, seizure, and decreasing of conscious

4). Long term impacts: unhealthy appearance, health and cleanness ignorance, unhealthy teeth, injection wound all over body (for users who inject the drugs/narcotic)

b. Change of Attitude and Behavior:

1). Decrease of academic performance, often being absent, not doing homework, being lazy, being irresponsible

2). Change of sleep pattern, staying up late, hard to wake up in the morning, fall asleep in class or working place.

3). Isolating, staying long time at the bathroom/restroom, resisting to meet family members at home

4). Often receiving phone-call and being visited by unknown people then disappear

5). Always lying and asking for a lot of money with different and unclear reason of what for the money is, taking and selling personal and family's properties, stealing, mumbling, being in the fight and being involved with police (crime).

6). Being emotional, being sensitive, getting angry, acting violently, self-isolating, and having lot of secret.

Moreover, the health impacts due to the drugs abuse is threaded to be infected by HIV and hepatitis. Based on the World Drug Report of 2017, almost 12 million people in 2015 use drugs by injection, and that is the key population of the decrease of HIV infection risk as the impact of unsafe injection in relation with contaminated needles and syringe.

Available data which are rarely show that globally new infected HIV increased from 114,000 in 2011 to 152,000 in $2015^{20}$

20 United Nations Office on Drugs and Crimes (UNODC), Op., Cit., Page 19 
Meanwhile, for Indonesia, based on the 2016 Indonesia Health Profile. Total number of new positive HIV which is reported from year to year has been increasing and in 2016, it was reported 41,250 cases. From that total, 1.9\% was caused by the using of drug injections. ${ }^{21}$

By seeing the destructive negative impacts of drugs (and medicine/hazardous material), it is mandatory for all parties especially government to prevent and eradicate the abuse and illegal trafficking of drugs (and medicine/hazardous material), therefore with the nature of drugs from one side as medicine or is beneficial in healthcare or science and on another side it is also cause addiction and harmful if it is used improperly, so it is required to be supervised thoroughly.

\section{Causes of Drugs Abuse}

In general, there are several factors that cause the abuse of drugs (and medicine/ hazardous material): individual factor, environmental factor, and drug factor itself. Firstly, the individual factor. Most of the abuse start from the individual factor and during teenagers because teenagers face certain changes of biologically, physically, or social therefore the tendency for them to get involved in drug is easy.

Secondly, environmental factor. Some factor that include in this factor are families, schools/education institution, social communities, and neighborhood. If there is no communication in the families, there will be no role model from parents, lack of attention from the parents and low quality of spiritual life that cause the drug abuse from the closest relationship, family. Moreover, the indiscipline school / education institution, the location that close to central of drug traffic also influence someone to be involved in drug.

Social environmental or friendship is a strong factor to influence the drug abuse. And also, the thing that is dangerous that the social community is susceptible to political, economic, and social aspect that may cause the drug abuse including the low law enforcement.

Thirdly, the drug factor itself. This factor is related to the trafficking of the drugs that has close connection with other factors, when it is easy for the people to from many classes get accesses to drugs, which then become the embryo of drug abuse. At this point, supply and demand meet where the request and the need of drug abuse comes, the trafficking of the drug have a chance to also grow.

Based on the research that done by Elviza Rahmadona and Elvi Agustin, there are 3 (three) dominant factors that cause the drug use: low spiritual level $(85.4 \%)$, friends role in the introduction of the drug abuse $(70.8 \%)$ and lack of family role $(41.7 \%){ }^{22}$

20 United Nations Office on Drugs and Crimes (UNODC), Op., Cit., Page 19

21 Untung Suseno Sutarjo et., al., 'Profil Kesehatan Indonesia Tahun 2016' (Kementerian Kesehatan R.I, 2017), Page 161-162

22 Elviza Rahmadona and Helfi Agustin, 'Faktor Yang Berhubungan Dengan Penyalahgunaan Narkoba Di RSJ Prof. HB. Sa'anin', Jurnal Kesehatan Masyarakat Andalas, Vol. 8.No. 2 (2014), Page 60-66. 
This research conclude that the cause of the drug abuse arises from internal and external factor. ${ }^{23}$ Following is the result of the research is set forth as follows:

\begin{tabular}{|c|c|}
\hline Category of the Cause of Abuse: & $\mathrm{n}(\%)$ \\
\hline \multicolumn{2}{|l|}{ Internal Factor } \\
\hline Easy to be influenced & $53(63.9)$ \\
\hline Trying new things & $49(59.1)$ \\
\hline Seeking for Compliment & $51(61.5)$ \\
\hline Following Trend & $65(78.4)$ \\
\hline Luxury Life Style & $53(63.9)$ \\
\hline Not confident & $47(56.6)$ \\
\hline Being addictive and want to try again & $83(100)$ \\
\hline Harming personal self and other peoples & $6072.3)$ \\
\hline \multicolumn{2}{|l|}{ External Factors } \\
\hline Prohibited by Religion & $61(73.4)$ \\
\hline Pressured Environment & $50(60.2)$ \\
\hline Curbed Family & $23(27.2)$ \\
\hline Broken Home & $62(74.7)$ \\
\hline Having family or relative that also drug users & $53(63.9)$ \\
\hline Having bad communication & $61(73.4)$ \\
\hline Not practicing religious life & $62(74.7)$ \\
\hline Being friends with the users & $73(87.9)$ \\
\hline Law prohibit using Drugs & $52(62.6)$ \\
\hline Getting the Drugs free & $43(51.8)$ \\
\hline Economic issue & $43(51.8)$ \\
\hline Getting Lack Attention from Government & $31(37.7 \%)$ \\
\hline
\end{tabular}

\section{Illegal Trafficking of Drug Cases}

Based on the newest data that issued by BNN, in 2017 there was 423 cases of drugs, its 597 suspects that consists of 592 of Indonesian Citizen, and 5 foreign Citizen. It is recorded that from January to June 2017, BNN has successfully seized evidence as it is shown in below chart. From the revelation of the above case, BNN also has took asset around Rp. 561.4 billion from 2010-2016. ${ }^{24}$

23 Catur Mei Wulandari., et., al., 'Faktor-Faktor Yang Mempengaruhi Penyalahgunaan Napza Pada Masyarakat Di Kabupaten Jember', Jurnal Farmasi Komunitas, Vol. 2.No. 1 (2015), Page 1-4

24 National Anti-Drugs Agency, 'Infsografis: Ungkap Kasus Narkotika 2017' (Badan Narkotika Nasional, 2017). 


\begin{tabular}{|c|c|c|}
\hline \multicolumn{3}{|c|}{ Seized Evidences } \\
\hline SABU & $236.306,80$ & GRAM \\
\hline EKSTASI & $108.590,25$ & BUTIR \\
\hline GANJA & $61,363,08$ & GRAM \\
\hline HEROIN & 4,60 & GRAM \\
\hline KOKAIN & 3,49 & GRAM \\
\hline KETAMINE & 93,23 & GRAM \\
\hline $\begin{array}{l}\text { 4CHOBOSETHCATHWOME } \\
\text { HCOCO }\end{array}$ & 50 & LITER \\
\hline 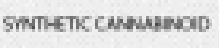 & 532,90 & GRAM \\
\hline
\end{tabular}

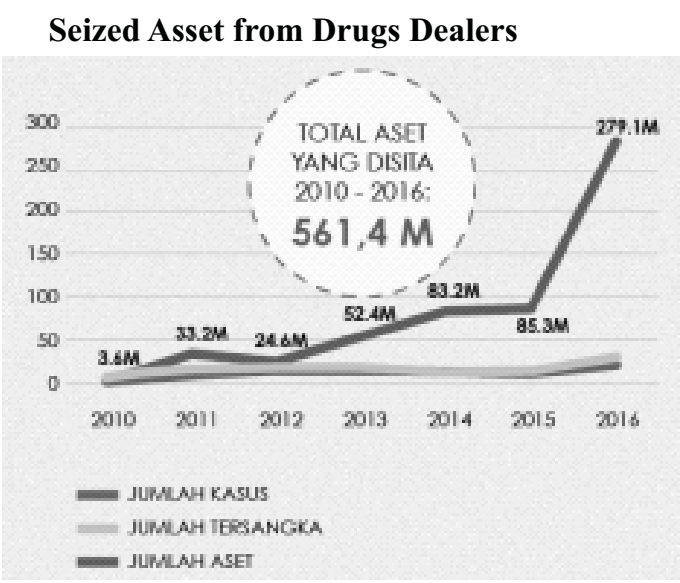

\section{Prevention and Eradication of Drugs Abuse and Illegal Drug Trafficking}

Revelation of the drug abuse and illegal drug distribution case, every year shows increment, that with such revelation of the case, slow but sure the drugs abuse and illegal drug trafficking can be controlled and prevented, even it can be eradicated. However, following the success of the case disclosure, in parallel the drugs abuse and illegal drug trafficking grows, it is proven with the revelation of the drugs maker factories in some places. It seems that the more the drugs abuse is eradicated, the more the drugs dealers spread out their actions.

Therefore, lot of efforts need to be done by developing ideas, concepts, and new insights in facing the drugs abuse and illegal drugs trafficking. This is required to be done to offset pattern, motives, and purpose of the illegal drug dealers. On the other hand, people need to be aware of the danger of the drugs.

In general, the Prevention and Eradication of the Drug Abuse and Illegal Drug Trafficking can be categorized into 2 (two) approaches:

a. Penal approach (criminal law approach): an approach that emphases to repressive (eradication) after the criminal act occurs with referring to criminal court system.

b. Non-penal (non-criminal): an effort to emphasize the nature of being "preventive" (prevention/control) before the criminal act occurs.

Based on Wijaya, the contribution on the prevention of the distribution of drugs include: ${ }^{25}$

a. Primary prevention or early prevention that address to individuals, families, or communities and people which have not been involved in the drugs abuse and trafficking issues with the aims to make them be aware and have defense to refuse and fight.

25 Ira Helviza, Zulihar Mukmin, and Amirullah, 'Kendala-Kendala Badan Narkotika Nasional (BNN) Dalam Penanggulangan Penyalahgunaan Narkotika Di Kota Banda Aceh', Jurnal Ilmiah Mahasiswa Pendidikan Kewarganegaraan Unsyiah, Volume 1.Nomor 1 (2016), 128-146(Page 140). 
b. Secondary prevention or sensitiveness prevention, this is addressed to the group or communities that very sensitive to be affected by drugs, such as living in the inappropriate neighborhood or work in clubs. The aim is to make them become stronger to fight the persuasiveness or fors cheesiness from outsiders or arising from their own selves

c. Tertiary prevention or prevention towards the seasonal addicts which have followed therapy and rehabilitation program to end their addiction. The prevention is done in the family, school, community, workplaces and public places, through communication, information and education activities that use lot of media that maybe adjusted with the condition.

Prevention and illegal trafficking of drugs is a social problem which at the same time also a legal issue in society. Handling of the drug abuse is done through directed policy which legal instrument such as rules and regulations as the basis. Therefore, the enactment of Law No.35 of 2009 regarding Drugs is the basis of prevention and handling of the drug abuse and illegal drug trafficking.

There are several legal politics that are important in the Law of Drugs as the direction of the policy to govern the drugs in Indonesia:

a. To protect people from the danger of the drugs and prevent and eradicate the illegal trafficking of drugs. In this Law, it has been governed regarding drug precursor which has a role as the substance to make drugs. In addition, it also conducts the penalty of the drug precursor misuse.

b. To incur deterrent towards the suspects of the drug abuse and illegal drug trafficking and drug precursor, there have been penalties (prion charge), both special minimum criminal sanctions for 20 (twenty) years, lifetime prison, and death penalty. The penalties are determined based on the types, class, size, and amount of the drugs

c. To make the prevention and eradication of the drug abuse and illegal drug trafficking more effective, it has governed regarding the strengthen of BNN institution. Such BNN is established based on Regulation of President No. 83 of 2007 regarding National AntiNarcotics Agency and City/Regency Anti-Narcotics. The BNN is a non-structural institution that based under and responsible to President which has a duties and functions to coordinate. In this Law, BNN has been formed as non-ministry governmental institution $(L P N K)$ and has an authority to investigate and interview. BNN is under President and responsible to him. BNN has representatives in provinces, cities/regencies as vertical institution which are BNN Province and BNN City/Regency

d. To strengthen the institution, it is also governed that all the property that resulted from drugs and drug precursor and money laundering referring to binding court's decision will 
be taken for the state and use for the prevention and eradication of drug abuse and illegal drug trafficking and drug precursor and effort of medical and social rehabilitation.

e. In this Law is also governed regarding the expansion of the wiretapping interview technic, under cover buy technic, and controlled delivery technic and other investigation to trace and arrest the drug abuse and illegal drug trafficking and drug precursor.

f. For the organized drug abuse and illegal drug trafficking and has wide network that across international territory, this law also governs about the rules and regulation on how to have either bilateral, regional or internal cooperation.

g. Lastly, this Law conducts the role of the people's contribution in preventing and eradicating the drug abuse and drug precursor including giving appreciation to people that have certain dedication of the prevention and eradication. Such appreciation is given by law enforcement officers.

\section{Obstacles and Efforts in Preventing and Handling the Drug Abuse and Illegal Drug Trafficking in Indonesia}

\section{Juridical Factors}

Law of Drugs originally has humanist soul to the addicts and victims of drug abuse as it stated in Article 54 of Law of Drugs that mention the drug addicts and victims must enter medical and social rehabilitation. On the other hand, strict approach towards to any person with no rights and break the law, plant, own, keep, posses, and provide drugs and/or drug precursor, criminal penalty, fine and death penalty will be charged.

The thing that is always be a problematic issue is that there is a pro and cons in society due the miss-interpretation and mis-implementation of the law where in some cases the investigators use incorrect article to the addicts and victims.

\section{Institutional and Administrative Factors}

Danger of drug abuse and illegal drug trafficking has been spread out to all class of peoples including the law enforcement officer. Despite the addictive factors, economy factor become the main reason of the involvement of law enforcement officer in the drug world circle.

It has been found that in many cases the officers become the protector ad even the main actor of the syndicate. From Indonesian Army, officers, Correction Institution and Lectures, all are involved in the drug abuse and illegal drug trafficking.

This condition is surely contra-productive with the effort to prevent and eradicate the drug abuse and illegal drug trafficking and it must be stopped by optimizing the supervision and strict acts. 


\section{Environmental and Social Factor}

Social and environmental factor becomes the key factor to determine either success and failure of the "war" against the drug abuse and illegal drug trafficking. This is because, although the effort from the government and law enforcement officers have been done well but when the society do not support, all the goal will be useless. Moreover, in the prevention trial, social and personal control must be the main key to prevent and eradicate the drug abuse and its illegal trafficking.

The factor which defined herein began with the people from family, schools/educational environment, friendship and other general communities. There are still lot of people who think that it is a shame if there is a family member who become addicts therefore the ignorance of people to the family so that the addicts become more addictive and from being victims and become suspect.

Lack of knowledge of people on drugs become one of the obstacle in the process of the prevention and eradication of the drug abuse and its illegal trafficking. In addition, the care level of the people and defense towards the drug abuse is still low. Such care can be seen from the active act of the people to participate to the police or law enforcement officer about indication of drug abuse and its illegal trafficking.

\section{Closing}

\section{Conclusion}

1. The prevention and handling of the drug abuse and illegal drug trafficking is conducted with two approaches: penal approach (criminal) and non-penal approach (non-criminal) with emphasizing the balance of handling pattern between demand reduction and supply reduction. The prevention and its alternative idea has been systematically and comprehensively done through the enactment of Law No. 35 of 2009 regarding Drugs that govern entire forms of activities and/or actions relating to drugs and drug precursor.

2. Some of the obstacle of the prevention and handling of drug abuse and its illegal trafficking cannot be separated from the obstacle that can influence the performance of the prevention and eradication. Such obstacle includes juridical factor which is related to the law enforcement in concerto. And, another factor is the factor from the officer, institution, and the people.

\section{Recommendation}

1. Government through the related ministry: BNN, BNP, BNPK, and National Police (POLRI) must optimize the campaign of anti-drugs with the target to all class of people either in city area or urban area by using diverse information media. Moreover, the 
empowerment of the people also needs to be enhanced by forming the group of people who fight the drugs and through partnership with many parties, education world, business and communities.

2. Prevention and eradication of the drug abuse and its illegal trafficking needs to be made as priority of government's vision with certain limited target time.

\section{Bibliography}

\section{Books:}

Departemen Kesehatan R.I, Buku Pedoman Praktis bagi Petugas Kesehatan (Puskesmas) Mengenai Penyalahgunaan Narkotika Psikotropika Dan Zat Adiktif Lainnya (NAPZA) (Jakarta: Perpustakaan Departemen Kesehatan R.I, 2001)

Faisal Abdul Naseret., al., Hasil Survei Penyelahgunaan Dan Peredaran Gelap Narkoba Pada Kelompok Pelajar Dan Mahasiswa Di 18 Provinsi Tahun 2016 (Jakarta: Badan Narkotika Nasional Bekerjasama Dengan Pusat Penelitian Kesehatan Universitas Indonesia, February 2017)

Mufti Djusnir, et.al, Survei Prevalensi Penyalahgunaan Narkoba Pada Kelompok Rumah Tangga Di 20 Provinsi Tahun 2015 (Jakarta: PusatPenelitian Data dan Informasi Badan Narkotika Nasional Republik Indonesia, 2016)

Pusat Data dan Informasi Kementerian Kesehatan RI, 'Anti Narkoba Sedunia 26 Juni'17' (Pusat Data dan Informasi Kementerian Kesehatan RI, 2017)

Russel Butar-butar, "Kompilasi Hukum Pidana dan Aplikasinya Di Masyarakat", Pondokgede Bekasi, Gramata Publishing,2016, Hlm.139.

SabarinahPrasetyo, and Diah Setia Utami, 'Preverensi Sekunder Pemakaian Zat Adiktif', Buletin Jendela Data Dan Informasi Kesehatan, 2014

United Nations Office on Drugs and Crimes (UNODC), World Drug Report 2017 - GLOBAL OVERVIEW OF DRUG DEMAND AND SUPPLY $\square$ : Latest Trends, Cross-Cutting Issues, Booklet 2 (Vienna-Austria: Division for Policy Analysis and Public AffairsUNODC, May 2017)

UntungSusenoSutarjoet., al., 'ProfilKesehatan Indonesia Tahun 2016' (Kementerian Kesehatan R.I, 2017)

\section{Laws:}

Undang-undangNomor 5 Tahun 1997 tentangPsykotropika 
Endeh Suhartini, Martin Roestamy, Ani Yumarni : Prevention And Eradication Of Drug ......

Undang-undangNomor 35 Tahun 2009 tentang Narkotika

Peraturan Menteri Kesehatan Nomor 2 Tahun 2017 tentang Perubahan Penggolongan Narkotika.

Peraturan PresidenNomor 83 Tahun 2007 tentang Badan Narkotika Nasional

\section{Other resources:}

Badan Narkotika Nasional, 'Info grafis? : Ungkap Kasus Narkotika 2017' (Badan Narkotika Nasional, 2017)

BNN, 'Infografis : Hasil Survei Penyelahgunaan Dan Peredaran Gelap Narkoba Pada Kelompok Pelajar Dan Mahasiswa Di 18 Provinsi Tahun 2016' (BNN, 2016)

Catur Mei Wulandari, DiyanAjengRetnowati, Kukuh Judi Handojo, and Rosida, 'FaktorFaktor Yang Mempengaruhi Penyalahgunaan Napza Pada Masyarakat Di Kabupaten Jember', Jurnal Farmasi Komunitas, Vol. 2 (2015), 1-4

Elviza Rahmadona, and Helfi Agustin, 'Faktor Yang Berhubungan Dengan Penyalahgunaan Narkoba Di RSJ Prof. HB. Sa'anin', Jurnal Kesehatan Masyarakat Andalas, Vol. 8 (2014), 60-66

Endeh Suhartini, Legal Persfektive of Medical Care System For Prisoner and Detainees,International Journal Of Ciivil Engineering and Technology , 8 (9), 2017,pp.406 - 412. http://www.iaeme.com/IJCIET/issues.asp?JType+IJCIET\& VType $=8 \&$ IType $=9$

Erma Rusdiana, Mediation Existence Criminal Penal Settlement, Journal UNTAG Law Review (ULREV), Volume 2, Issue 1, May 2018, PP 31-43, http://jurnal.untagsmg.ac.id/indeks.php/ulrev/indeks

Fransiska Novita Eleanora, 'Bahaya Penyalahgunaan Narkoba Serta Usaha Pencegahan Dan Penanggulangannya (Suatu Tinjauan Teoritis)', JurnalHukum, Vol. XXV (2011)

Hj.Rodliyah dam H.Salim HS. "Hukum Pidana Khusus ,Unsur dan sanksi Pidananya”, Depok, RAJAWALIPERS,2017

Ira Helviza, ZuliharMukmin, and Amirullah, 'Kendala-Kendala Badan Narkotika Nasional (BNN) Dalam Penanggulangan Penyalahgunaan Narkotika Di Kota Banda Aceh', Jurnal Ilmiah Mahasiswa Pendidikan Kewarganegaraan Unsyiah, Volume 1 (2016), $128-46$

SyamsulHidayat, "Peranbadan Narkotika Profinsi Nusa Tenggara Barat dan Polisi Resort Kota Mataram Dalam Menangulangi Pengedaran Dan penyalahgunaan Narkoba 
Endeh Suhartini, Martin Roestamy, Ani Yumarni : Prevention And Eradication Of Drug ......

(Studi Di Kota Mataram), Jurnal Hukum Jatiswara Fakultas Hukum Mataram, Volume 31 Nomor 1-2 Maret 2016 ISSN. 0853-392X,Hlm.137.

Wikipedia, 'Narcotic', Wikipedia The Free Encyclopedia, $2017<$ https://en.wikipedia.org/ wiki/Narcotic $>$ [accessed 25 January 2018] 